Valóságos könyvtár - könyvtári valóság. Könyvtár- és információtudományi tanulmányok 2020. Szerk. Kiszl Péter, Boda Gáborné Köntös Nelli.

Budapest, ELTE BTK Könyvtár- és Információtudományi Intézet. 2021. 347-358.

\title{
KÉPZELT RIPORT EGY CHATBOT ÉPÍTÉSÉRŐL
}

\author{
WINKLER BEA \\ Állatorvostudományi Egyetem Hutÿra Ferenc Könyvtár, Levéltár és Múzeum, \\ könyvtárigazgató
}

\section{TARTALMI ÖSSZEFOGLALÓ}

A könyvtárak évezredek óta a tudás őrzőiként léteznek. Hol csupán a kiválasztottaknak, hol minden érdeklődőnek elérhetővé tették a falaik között ôrzött temérdek információt, a szórakoztatást és kikapcsolódást vagy a fejlődést segítő tartalmakat.

A XXI. századdal, az internet és a mobiltechnológia korában olyan változások következtek be, amelyek a könyvtárak XX. században megszokott szerepét újragondolandóvá tették. Olyan fogalmak, mint a hálózatok, a gépi tanulás, a mesterséges intelligencia a mindennapi közbeszéd részévé váltak. A könyvtárak az online térbe is beköltöztek, funkciójuk és az általuk nyújtott szolgáltatások egy részét pedig átemelték oda. Van azonban egy olyan szerepkör, a gyorsan elérhető információké, ahol a sokszereplőssé vált piacon a könyvtárak jelentős hátrányba kerültek.

A mesterséges intelligencia hétköznapi feladatokban való részvétele folyamatosan növekszik, ezért ezen a területen a könyvtáraknak is meg kell találniuk az őket segítő lehetőségeket. A napjainkban már sokadik fellángolását élő chatbotok könyvtári alkalmazása lehet az egyik ilyen.

A tanulmány egy gondolatkísérlet, amely egy könyvtári chatbot bevezetése körül felmerülő kérdésekre, feladatokra, problémákra igyekszik felhívni a figyelmet. A munka célja, hogy kiegyensúlyozottan és a lehetőségekhez képest igazságosan mérje fel a feladatot, elkerülve a túlzott aggodalmaskodást, a filozofálgatást és a hurráoptimizmust egyarát.

\section{Bevezetés}

A könyvtári munka egyik jelentős szelete a használókkal, látogatókkal, olvasókkal, érdeklődőkkel, ügyfelekkel stb. történő kommunikáció. Az ember és a számítógép közötti interakciót évtizedek óta kutatják, a tudósok/fejlesztők sok időt, pénzt és energiát fektettek az egyre újabb, és talán jobb grafikus felületek fejlesztésébe. Napjainkra azonban az eddig vágyott grafikus felületek helyett az emberek érdeklődése a természetes nyelven történő írásbeli párbeszéd (chat), tehát a görgetés, klikkelés vagy gombok nélküli kommunikáció felé fordul. ${ }^{1}$ A számítógéppel történő chat vagy csevegés lehetősége évtizedek óta többé-kevésbé szem előtt van, azonban a benne rejlő lehetőségek valódi kiaknázása csak néhány éve kezdődött. A chatbotok célja az, hogy kapcsolatba lépjenek az emberekkel, ezért a könyvtárak és könyvtárosok számára is érdekes területét alkotják a mesterséges intelligenciát alkalmazó technológiáknak. 


\section{WINKLER BEA}

A chatbot olyan számítógépes program, amellyel szóban vagy írásban folytathatunk társalgást, aminek célja valamely információ átadása vagy más szolgáltatás nyújtása. ${ }^{2}$ Az első múködő chatbotnak a Joseph Weizenbaum 1966-ban megjelent cikkében bemutatott Elizat tartják. ${ }^{3}$ A chatbotok a természetes nyelv használatával kommunikálnak az emberekkel. ${ }^{4}$ A könyvtárban múködő tájékoztatás pedig olyan terület, ahol első ránézésre jól lehetne hasznosítani az automatizálást, mert a „Meddig van ma nyitva a könyvtár?” kérdéstől, a szaktájékoztató specializált ismeretéig jól skálázható téma- és feladatkörökrôl beszélhetünk. A következőkben bemutatom, hogy a könyvtári kérdések megválaszolására alkalmazandó chatbot építésénél milyen kérdésekre érdemes felkészülni.

\section{Chatbot? Igen, chatbot!}

Egy jellemző prekoncepció, hogy a chatbot az ügyfélszolgálati munkatárs automatikus verziója, amelynek célja, hogy a távoli használóknak segítséget nyújtson. Könyvtárakra értelmezve, úgy is megfogalmazhatjuk, hogy a chatbot célja segítséget nyújtani az olvasóknak abban az időszakban, amikor a könyvtár zárva van. Ezzel a feltevéssel azonban leszúkítjük a saját lehetőségeinket. A chatbot ugyanis több, mint a „mikor lesz nyitva a könyvtár" kérdésre válaszolni képes három soros programkód. A chatbot sok tekintetben hasonlatosnak tűnhet egy honlaphoz is, hiszen bárki számára hozzáférhető, csupán egy számítógépre (telefon, tablet stb.) és internetkapcsolatra van szükség, hogy megkérdezzük és megkapjuk a választ. Azonban van egy lényeges, és a használók számára igen jelentős különbség a weboldalakhoz képest: nem kell megkeresni az információt, mert a chatbottól „csak” kérdezni kell és megadja a választ (szerencsés esetben, persze).

Az IFLA „Library policy and advocacy” blogján olvasható egy 2017-es bejegyzés, amely szerint „,a keresőmotorok már hosszú utat tettek a könyvtárak hagyományos szerepének megismétlésében, hogy segítsenek megtalálni az alapvető információkat - fővárosokat, dátumokat stb." ${ }^{5}$ Erre reflektálva azt gondolom, hogy a chatbot-technológia alkalmazásával a könyvtár lehetőséget teremthet magának, hogy a keresőkhöz hasonlóan gyorsan és a használó szempontjából egyszerúen válaszoljon meg akár speciális ismeretet feltételező kérdéseket. A chatbot nagy előnyének tekintik, hogy párhuzamosan, több klienssel is tud foglalkozni, gyors válaszadásra képes, és időkorlát nélkül hozzáférhető. Ugyanakkor a bevezetése, ha valódi előnyt szeretnénk kovácsolni a használatából, szakértelmet, sok háttérmunkát és folyamatos fejlesztést igényel. Az 1. táblázatban röviden összefoglalom a chatbotokkal kapcsolatban sokszor felmerülő pro és kontra érveket. 


\section{1. táblázat \\ A chatbot mellett és ellen használt érvek ${ }^{6}$}

\begin{tabular}{lr}
\hline Mellette szól & Ellene szól \\
\hline $\begin{array}{l}\text { gyors vevőszolgálat } \\
\text { vevői elégedettség } \\
\text { csökkenti a munkabér költséget } \\
\text { többcélú }\end{array}$ & limitált válaszadás \\
& frusztráció \\
& az összetett chatbot drága \\
& Alapok
\end{tabular}

Mielőtt elkezdnénk a minket megrendelőként és szolgáltatóként egyszemélyben leginkább érdeklő kérdéseket feltenni, érdemes felmérni, milyen lehetőségek is vannak a chatbotok alkalmazása során. Az emberek úgy szeretnének beszélgetni a számítógéppel (akár írásban, akár szóban), mint ahogy azt egymással teszik. ${ }^{7}$ Ez lenne a mi célunk is, a tökéletes beszélgetés élményét nyújtani a lehetô legpontosabb és legteljesebb válaszszal kombinálva. Ennek nemcsak a teljesség - pontosság elvárásának egyszerre történő teljesíthetetlensége szab határt, hanem még a technológia is.

A chatbotok egyik csoportja az, amely egyszerú, egymás után választható lehetőségeket kínál fel, akár vertikálisan, akár horizontálisan építkezve a lehetőségekből. Ez a döntési fa elvén múködik (1. ábra), ahol az egyik választás után következik a másik, néha visszalépési lehetőséggel kiegészítve. Ebben az esetben közel 100\%-ban biztosak lehetünk benne, hogy a kérdező, ha arra kíváncsi, amire számítottunk, pontosan a mi általunk megadott választ kapja. Ez önmagában csak egy pontosan behatárolt, speciális célra épített chatbot esetén lehet jó megoldás (pl. ha az e-könyv kölcsönzés lépéseit szeretnénk az opac megfelelő részén kommunikálni). Ebben az esetben ugyanis a kérdezőnek nincs szabadsága, nem tehet fel kérdést, csak azt tudja kérdezni (választani), amit mi előre beépítettünk.

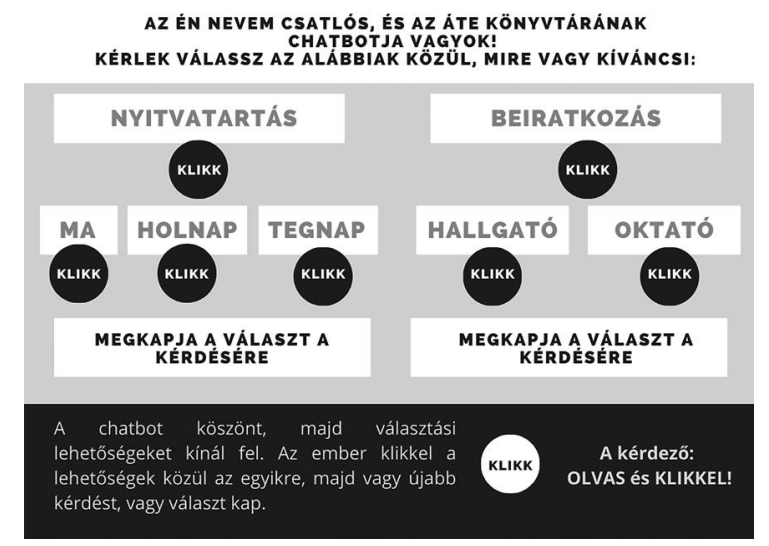

1. ábra: Egy döntési fával müködö chatbot müködésének sematikus ábrája - kérdésekekel és a válaszokekal 


\section{WINKLER BEA}

A másik a mesterséges intelligenciát jobban kihasználó lehetőség, hogy építünk egy kérdésekből, kulcsszavakból és válaszokból álló adatbázist, amelynek segítségével a chatbot tanul, és a kérdésekre fog tudni válaszolni. Ebben az esetben a természetes nyelvfeldolgozás segíti a chatbotot, hogy minél pontosabban megérthesse az ember által beírtakat. Ennek előnye és hátránya egyszerre a szabad kérdésfeltevés lehetősége.

A technikának több fontos alapeleme van, amelyek együttesen határozzák meg múködésének sikerességét, például az ismereteket tartalmazó adatbázis, a kulcsszavak megfogalmazása, illetve a mesterséges intelligencia (MI) kérdésfeldolgozása és mintaillesztése, válaszadása. Azonban nem szabad elfelejteni, hogy nem csak a megfelelő válaszok átadása fontos, hiszen a felhasználói élmény oldaláról tekintve a kérdést, nagyon sok múlik azon, hogy a kérdező mennyire érzi a válaszokat pontosnak és hitelesnek. Gondoljuk át, hogy mi történik egy hagyományos beszélgetés során, és vajon miben különbözik tőle egy chatbot beszélgetés? Az őszinte válasz, hogy jó esetben semmiben.

0. A felhasználó megnyitja az üzenetküldő oldalt.

1. A chatbot köszön - megjeleníti az első üzenetet.

2. A felhasználó ír valamit.

3. A chatbot
a. elolvassa,
b. értelmezi,
c. megpróbál választ találni rá,
d. választ ad.

4. A felhasználó
a. ír valamit $\rightarrow$ ismétlődik a 3. lépés,
b. nem ír semmit, lezárja a beszélgetést (kilép).

A mesterséges intelligencia, amely itt dolgozik, több különböző feladatot is végez: természetes nyelv feldolgozást, válasz generálását, illetve a szabályok és tanultak alapján a helyes válasz megtalálását. A felhasználó üzenete egy/több szó vagy mondat is lehet. Itt azonban nem csupán az egymás után írt kifejezések jelentése a lényeges, a chatbotnak arra kell rájönnie, mi volt az üzenetküldő szándéka. A beszélgetés kulcspontja, hogy a bot megérti-e a leírtak mögött a szándékot, helyesen értelmezi-e a leírtakat a szándék szempontjából.

A napjainkban elérhető chatbot-szolgáltatások különböző értelmező algoritmusokat használnak, amelyek más és más szemlélet és szabályok alapján határozzák meg a beszélő szándékát a leírt szavak mögött. Mikor chatbot létrehozásra gondolunk, át kell tekinteni a céljainkat, a használókat, az igényeiket és a mi elvárásainkat, hogy a legmegfelelőbb megoldást választhassuk.

A chatbotok és úgy általában a mesterséges intelligenciával segített szolgálatások emberi szemmel szinte követhetetlenül gyorsan képesek válaszokat generálni. A kutatók sokat foglalkoztak annak a kérdésnek az eldöntésével, hogy ez az emberi reakcióidőt messze megelőző válaszadás milyen hatással van a kérdezőre. Kíváncsiak voltak arra, 
hogy vajon zavarja-e a kérdezőt, ha a gép egy emberhez képest gyorsabban reagál a kérdéseire? Első érzésre számomra egyértelműnek tűnik a válasz, hogy nem zavarná, hiszen információt szeretne kapni, méghozzá minél gyorsabban. A kérdéskör tudományos megválaszolásához bevezették a chatbotok alkalmazása során a késleltetést, majd a dinamikus késleltetést. A késleltetés azt jelenti, hogy a chatbot nem akkor jeleníti meg a választ a képernyőn, amikor megvan, hanem a kérdésfeltevéshez képest legkorábban akkor, amikor az előre meghatározott idő eltelt. Ugyanez történik a dinamikus késleltetés esetén is, csupán ilyenkor például a beszélgetés előzményének szöveghosszából és a válaszadások reakcióidejéből kalkulálják ki a chatbot következő válaszának megjelenítési időpontját (vagyis a késleltetés hosszát).

Gnewuch, Morana, Adam és Maedche érdekes kutatási eredményekről számoltak be 2018-ban a European Conference on Information Systems konferencián, ugyanis kutatásukban azt találták, hogy a válaszadás során alkalmazott dinamikus késleltetés növelte a használói elégedettséget is. ${ }^{8}$ Vagyis az eredmények azt sugallják, hogy a gyors válaszadás helyett, a jól megválasztott késleltetés pozitívan befolyásolja az ember chatbotra adott reakcióit. Bátfai és Bátfai virtuális könyvtárosukról 2011-ben írt cikkében olvashatjuk, hogy izgalmas távlatokat nyithat meg Könyves Kálmán és a helyi integrált könyvtári rendszer (integrated library system = ILS) összekapcsolásának lehetősége. ${ }^{9}$

Az eddig bemutatottak jól szemléltetik, hogy a chatbotok mennyire összetett struktúrák és sok tekintetben az embert komolyan befolyásolható tényezőként kell tekinteni rájuk. Egy igazán jól működő bot nehezen megkülönböztethető egy embertől, és pont emiatt fontos, hogy használatuk során egyértelmű etikai szabályokat alkalmazzunk.

\section{Chatbot épitése - nulladik lépés: kérdések}

\section{Etikai kérdések}

A chatbot egy gép, amely emberi módon képes kommunikálni, s mint ilyen, fontos definiálni azokat a szabályokat, amelyek az ember-gép kommunikációt meghatározzák. Vajon a könyvtáros válaszára váró használót irányíthatjuk-e ember helyett egy chatbothoz? Mi van, ha nem megfelelő minőségú válaszokat ad majd a bot? Milyen, nem a válaszok minőségét érintő kritériumok alapján lehetünk biztosak abban, hogy az érdeklődő érteni fogja a helyzetet? Fichter és Wisniewsky 2017-ben a következő szempontokat adta meg, mint a jó bot (good bot) ismérvei:

- jól behatárolt területen múködik és megmondja, pontosan mire képes;

- biztos és jól körülhatárolt céllal rendelkezik;

- becsületes és őszinte;

- barátságos, inkluzív nyelvet használ és még egy kis (hamis) humorérzéke is van;

- megnyerően viselkedik, akkor is, ha hibázik. ${ }^{10}$

Az öt pontba foglaltak biztosítják azt is, hogy az ember mindig tudja, hogy egy chatbottal és nem egy emberrel beszél. A fenti tulajdonságoknak minél inkább megfelelő bot 


\section{WINKLER BEA}

létrehozása szerintem az esetleges hiányosságok és a múködés esetén felmerülő problémák ellenére mind a használók, mind a könyvtárosok érdekeit egyaránt szolgálja, így ezt érdemes szem előtt tartani a fejlesztés során.

\section{A célok meghatározása}

Jelen kísérletünkben az Állatorvostudományi Egyetem (ÁTE) Hutjra Ferenc Könyvtár, Levéltár és Múzeum könyvtára (továbbiakban: Könyvtár) számára akarunk chatbotot létrehozni. A Könyvtár négy különböző, eltérő elvárásokkal rendelkező célcsoportot szolgál ki: 1) az egyetemi hallgatókat, 2) az egyetemi oktatókat, kutatókat és dolgozókat, 3) az állatorvosokat és 4) a külső érdeklődőket. A célcsoport meghatározásakor olyan, akár heterogén csoportot érdemes keresni, amelynek van olyan igénye, kérdése, amely jól körül határolható és várhatóan nyitott az új technikai megoldásokra is. Nálunk ők a legnagyobb személyes jelenlétet is produkáló, a hallgatókból álló használói csoport. Az ÁTE hallgatói létszáma körülbelül 1700 fő, ebből az érvényes könyvtári beiratkozással rendelkezők száma 1185 fő (2019. október 27-én), több mint egyharmaduk volt aktív (kölcsönző vagy új beiratkozó) könyvtárhasználó 2019-ben, úgy, hogy a könyvtár helyben használatához, tanuláshoz, olvasáshoz nincs szükség könyvtári beiratkozásra.

A feltett vagy megfogalmazódó kérdések köre a hallgatók tanulmányi előrehaladásával párhuzamosan változik. A hat és fél éves képzés során felmerülő témák köre azonban túl széles egy kísérleti (pilot) projekt keretében tervezetthez képest, ezért érdemes a sokszor ismétlődő és automatizált módon megválaszolható kérdéskörökkel foglalkozni. A diplomadolgozat írással kapcsolatos formai (és kisebb részt tartalmi) kérdések, mint jól behatárolható témák, a pontosan meghatározható célközönség (hallgatók), a konkrét, ismétlődő kérdések (konkrét válaszokkal) és a biztos érdeklődés a témák iránt, kiváló alapnak tủnik egy chatbot pilot projekthez.

\section{A chatbot elérhetösége}

A tervezett célcsoport lehetséges elérése szerint kell meghatározni a platformot vagy platformokat, ahol a chatbot elérhető lesz. Több elterjedt megoldás is létezik, ezek közül egy a honlapon elhelyezett chatbot, egy másik pedig az üzenetküldő szolgáltatásokban mûködő (de a kettő egyszerre is megvalósítható az üzenetküldő szolgáltatás honlapba integrálásával). Működhet például a Facebook Messengerben, Skype-on, de akár a telefonok SMS hálózatán is. A Facebookon elérhető egyetemi hallgatói csoportok múködését látva el kellett gondolkodni azon, hogy a Facebook üzenetküldő felületébe integrálva hozzuk létre a chatbotot. Miután meghatároztuk a célcsoportot és a megválaszolni kívánt kérdések körét, felmerült, hogy közzétegyünk-e egy speciális igényekre szabott chatbotot egy általános nyilvános felületen, miközben feltételezhető, hogy a használók sok olyan kérdést fognak ott feltenni, amire a bot nem tud válaszolni.

A 2. ábrán egy minta képernyőkép található Csatlós, a könyvtári chatbot köszöntő üzenetével, amelyet a Facebook Messenger szolgáltatásban láthatnának a látogatók. 


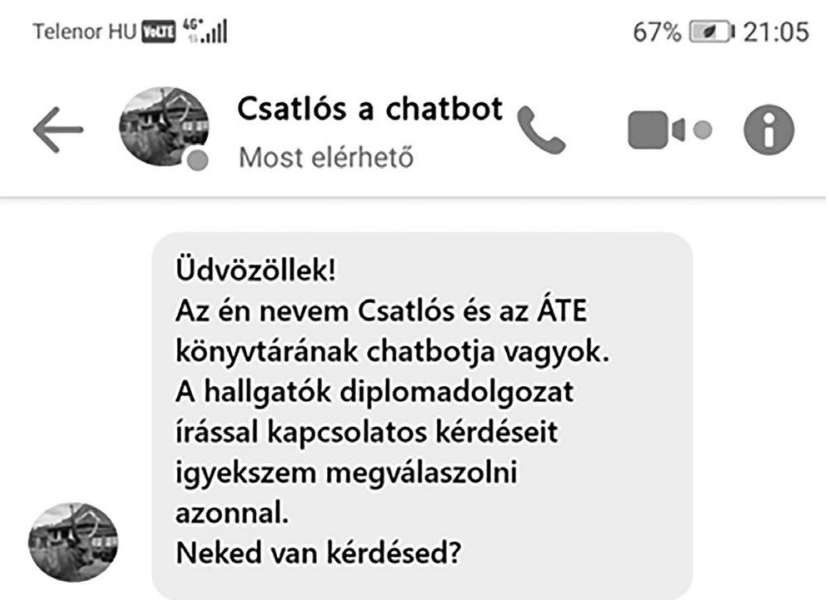

2. ábra: A chatbot üdvözlō szövege a Facebook. Messenger szolgáltatásában

A fenti bekezdésből következik, hogy nem a Facebook lesz a megcélzott platform, hanem első körben a diplomadolgozat-írást segítő könyvtári oldalakon tesszük majd elérhetôvé. A bevezetéskor és a későbbi népszerűsítésben, kommunikációnkban olyan hívószavakat fogunk alkalmazni, amelyek a célcsoportunk számára érdekesek, a többieknek pedig figyelemfelkeltők. Ilyen lehet, ha a chatbot népszerűsítésére használt anyagokban együtt szerepeltetjük, hogy diplomadolgozat-írás, segitség, azonnali válaszok, gyors segitség stb.

\section{Besžerzés, fejlesztés}

Napjainkban számtalan ingyenes és sokféle fizetős formában érhető el chatbot bárki számára. A Google keresőben a „chatbot fejlesztés” kifejezésre több mint 41 ezer találatot kaphatunk. Léteznek dobozos szoftverek, egyedi fejlesztők, nagy és kis cégek, közösségek, akik mind-mind chatbotot kínálnak.

Legkésőbb a beszerzés előtt fel kell mérni, hogy saját intézményünkben milyen, a fejlesztéshez, bevezetéshez, illetve a fenntartáshoz szükséges kompetenciák, munkaidő keretek és technikai háttér érhető el. Lényeges kérdés, hogy ki miben és hogyan tudna támogatni minket és miért tenné ezt meg. Előzetesen érdemes tehát felmérni, hogy célunk elérésének milyen várható hatása lesz a használókra, a könyvtárra, a könyvtárosokra és a fenntartóra, hogy lássuk azt is kinek, milyen érdeke fűződhet a bevezetéshez.

A hallgatókat projektünk két oldalról is segítené, a chatbot bevezetése az azonnali tájékoztatással és a megválaszolt kérdések személyes könyvtári konzultáción való felmerülésének elmaradásakor az egyéb témájú, akár a diplomadolgozat írásával kapcsolatos könyvtárosi segítségnyújtásra szánható időkeret növekedésével. Jelen helyzetben, amikor a képzett könyvtári munkaerő komoly érték a könyvtár számára, jelentős előny lehet, hogy egyes automatikusan is megválaszolható kérdéseket a chatbotra bízunk. 


\section{WINKLER BEA}

Az eddigi tapasztalatok alapján az egyetem részéről vélhetően támogató közegről beszélhetünk egy olyan technikai újítás kapcsán, amelynek konkrét célja a hallgatók támogatása tanulmányaik elvégzésében.

A chatbot indítása mindenképpen anyagi jellegű kérdés is, akár belső vagy külső erőforrásokra, akár mindkettőre támaszkodunk. Az automatizálás ezen a területen valójában nem egy az egyben munkabér- és költségcsökkentő tényező, amely már rövidebb távon is helyettesítheti az emberi munkát, mert maga a fejlesztés, bevezetés és a fenntartás komoly költségekkel jár. A költségek között minden belső és külső erőforrást figyelembe kell venni, amelyek szükségesek, a saját kollégák által befektetett munkát, munkaidôt is.

Amikor megvan a célunk és az elvárások, tudjuk mit akarunk, elkészítjük a dokumentációt, amelyben a szükséges alapossággal, de a részletekben el nem veszve összefoglaljuk, milyen elvárásaink vannak a majdani chatbottal (és a leendő partnerrel szemben). A dokumentáció elkészítéséhez, ha van rá lehetőség, érdemes informatikussal vagy chatbot szakértővel konzultálni, aki a késôbbiekben is segítheti a munkánkat. Külső szakember vagy legalábbis nem csak könyvtáros szakértelem bevonása komoly előnyökkel járhat, már ami a pilot projekt sikerességét illeti. Egyetemi könyvtárként több olyan szervezeti egység is van intézményünkben, amelyekkel együtt kell, illetve lehet dolgozni egy chatbot pilot projekten. Ilyen például az Informatikai és Biztonsági Igazgatóság, akikkel technológiai és fejlesztési kérdésekben, vagy a Kommunikációs és Nemzetközi Kapcsolatok Osztálya, akikkel az egyetem kommunikációjához való illeszkedésről, az ő esetleges hasonló terveikről és a meglévő/készülő egyetemi anyagokban való elhelyezésről egyeztethetünk. A Tanulmányi Osztály bevonásával a hallgatók még szélesebb körének elérésére törekednénk, illetve náluk felmerülő, a diplomadolgozat-írással kapcsolatos kérdések megválaszolását tennénk elérhetôbbé. Ezen felül az oktatóktól hozzájuk érkező, diplomadolgozatokkal kapcsolatos visszajelzéseket is hasznosíthatjuk ezáltal.

\section{Idó, idô és idô}

Az időtényező számtalan formában van jelen egy chatbot készítés során. Az első az az idő, amit előzetes tájékozódással, a terület megismerésével és a saját elképzeléseink öszszefoglalásával kell tölteni. Heteket, hónapokat lehet az előkészítő munkára fordítani, az előzetes ismeretek függvényében. Ezt követi az az idő, amikor kiírjuk a pályázatot és lebonyolítjuk az adott intézmény beszerzési szabályzatának megfelelően. A szakasz hossza sokban függ a dokumentáció/árajánlatkérés részletességétől, egyértelműségétől, a lehetséges partnerek számától, a felmerülő kérdések mennyiségétől, a szervezet szabályaitól és a hivatalos szervekhez benyújtandó anyagoktól. Az utolsó szakasz magának a tényleges fejlesztésnek az ideje. Ennek hossza is sok tényező függvénye, azonban három hónapnál nem valószínű, hogy rövidebb idő, egy év után pedig érdemes lehet elgondolkodni, hogy 
- reális célt tűztünk-e ki magunk elé,

- megtettünk-e mindent a siker érdekében,

- a megfelelő partnert választottuk-e ki.

\section{A chatbot tudása}

A fejlesztés ezen, tartalmi része rajtunk, könyvtárosokon fog múlni. Ugyanis, lehet akármilyen szofisztikált a chatbot, azonban addig, amíg mi magunk el nem készítjük számára a megfelelő formában a múködéséhez szükséges ismeretanyagot, semmit nem fog érni. Ez nagyon szép, ugyanakkor nagyon nehéz feladat. A chatbot tudását képező anyagot sok esetben egy adatbázisként, táblázatként adhatjuk át a fejlesztőnek, ahol kérdések, válaszok, kulcsszavak és esetleg csoportosításra lehetôséget adó kategóriák is leírásra kerülhetnek. A chatbot tudását képező anyagok elkészítése során mindvégig szem előtt kell tartani, hogy

- mindenre nem alkalmas a chatbot és mindenre nem is tud válaszolni,

- a túl általános vagy túl specifikus kérdés nem jó,

- a szakzsargon csak indokolt esetben segíti a használót,

- legyenek minél egyértelműbbek a megfogalmazások.

A 2. táblázałban bemutatunk néhány lehetséges kérdést a hozzá tartozó válaszokkal együtt.

\section{2. táblázat}

Minta adatok egy chatbot készitéséhez, hasznnálható táblázat formájában

\begin{tabular}{|l|l|l|l|}
\hline \multicolumn{1}{|c|}{ Kérdés } & \multicolumn{1}{|c|}{ Válasz } & Kulcsszavak & Kategória \\
\hline $\begin{array}{l}\text { Milyen hosszú le- } \\
\text { gyen a dolgozat? }\end{array}$ & $\begin{array}{l}\text { Irodalomjegyzékkel együtt minimum } 30 \\
\text { oldal. }\end{array}$ & $\begin{array}{l}\text { terjedelem, } \\
\text { oldalszám }\end{array}$ & formai \\
\hline $\begin{array}{l}\text { Milyen betűtípust } \\
\text { használjak? }\end{array}$ & $\begin{array}{l}\text { Times New Roman-t, mert az az ajánlott } \\
\text { betútípus. }\end{array}$ & $\begin{array}{l}\text { betűtípus, be- } \\
\text { túfajta, font }\end{array}$ & formai \\
\hline $\begin{array}{l}\text { Hogyan kell szó } \\
\text { szerint idézni egy } \\
\text { szövegrészt? }\end{array}$ & $\begin{array}{l}\text { Az átvett szövegrészt idézőjelek közé kell } \\
\text { tenni, mellette szövegbeli hivatkozást kell } \\
\text { alkalmazni, és az irodalomjegyzékben meg } \\
\text { kell adni az idézett szöveg pontos oldalszá- } \\
\text { mát az idézett múvön belül. }\end{array}$ & formai \\
idézek & & \\
\hline $\begin{array}{l}\text { Mi az a szövegbeli } \\
\text { hivatkozás? }\end{array}$ & $\begin{array}{l}\text { Szövegbeli hivatkozás esetén a szövegben az } \\
\text { idézett múre utalni kell az ún. Harvard stílu- } \\
\text { sú hivatkozással vagy sorszámozással. }\end{array}$ & $\begin{array}{l}\text { szövegbeli hi- } \\
\text { vatkozás }\end{array}$ & formai \\
\hline
\end{tabular}

\section{A chatbot tesztelése}

Az általunk leírt és megvalósítani kívánt chatbot tesztelése többlépcsős feladat. Az első lépcső a technika tesztelése, amikor a chatbot válaszadási képességét teszteljük, de még nem a tartalom, csupán a technikai oldalról. A tesztelés során ekkor például a következő kérdésekre kell igen választ kapni: 


\section{WINKLER BEA}

- A chatbot elérhető, ha odalátogatok az oldalra?

- Kapok-e üdvözlő üzenetet a bottól?

- Válaszol-e valamit, ha írok?

- Megfelelően jelenik meg az oldal/ablak különféle eszközökön?

A technikai hátteret folyamatosan nyomon kell követni, mind a rendelkezésre állást, mind pedig a sikeres és sikertelen kapcsolódásokat. Mikor a chatbot már rendelkezik az általunk összeállított tudásanyaggal és használni is tudja, elkezdődik a tesztelés második szakasza. Ezt a tesztelést több körben, többféle felhasználói csoporttal, kérdésfeltevési metódussal kell elvégezni.

A belső teszt során több egymásra épülő lépésben a kérdések és válaszok ismeretében teszteljük a chatbot múködését. Ehhez a lépéshez érdemes előre meghatározni néhány olyan kulcskérdést, amelyet többféle módon is tesztelni szeretnénk, akár az egyértelműsége akár a nehézsége miatt.

Nulladik szint, amikor az általunk eredetileg megadottal teljesen egyező formában feltett kérdésre azt várjuk, hogy 100\%-ban helyes választ adjon.

A következőkben nehezítjük a bot dolgát és teszteljük, hogy mennyire képes megtalálni a helyes választ, ha a feltett kérdés eltér a megadottól. A következókben megosztok néhány lehetséges teszt esetet, ha az alapkérdés a „Milyen hosszú legyen a dolgozat?" volt.

- Kihagyunk szavakat a mondatból, például: Milyen hosszú legyen?

- Megváltoztatjuk a szavak sorrendjét, például: A dolgozat milyen hosszú legyen?

- Véletlenül elgépelünk egy vagy több szót, például: Milyen hosszú legyen a doglozat?

- Szinonimát használunk egyes szavak helyett, például: Milyen hosszú legyen a szakdolgozat?

- Teljesen más szavakkal kérdezzük meg, például: A diplomadolgozatnak van elvárt minimum oldalszáma?

Chatbotunk a felsorolt esetekben a pontos kérdéseket kivéve nem valószínű, hogy minden kérdésnél 100\%-ot megközelítő teljesítményt fog nyújtani, de ez nem is elvárás. A véletlen elgépelések esetén magasabb, a szinonimák esetén kissé alacsonyabb, de általánosságban elvárható, hogy 50-60\% körüli arányban értelmezze helyesen az így feltett kérdést. A kollégák, majd pedig a használók „,vaktesztelése” során egyre valósabb képet kaphatunk a chatbot majdani múködéséről, azonban sosem szabad megfeledkezni arról, hogy a tesztelés a bevezetés napján nem befejeződik, hanem akkor kezdődik el igazán. Az éles múködést folyamatosan nyomon kell követni (a GDPR szabályoknak megfelelően) és a felmerülő hibákat javítani ajánlatos, illetve a tapasztalatok alapján kell továbbfejleszteni, finomítani a chatbot mûködését. 
KÉPZELT RIPORT EGY CHATBOT ÉPÍTÉSÉRŐL

\section{Összefoglalás}

Az ÁTE könyvtárának diplomadolgozat-írást segitő chatbotját példaként véve röviden áttekintettük egy könyvtári chatbot megalkotásakor felmerülő lépéseket. Kezdve a szabad kérdésfeltevést lehetővé tevő chatbot technológiától és néhány fogalomtól, mint például a dinamikus késleltetés vagy a jó bot tulajdonságai. A tervezett célunk a hallgatók diplomadolgozat-írásának támogatása, azonnali válaszadásra képes automatizált megoldással. A chatbot múködési felületeként a könyvtár honlapjának témába vágó oldala lett meghatározva, ezzel szűkítve a lehetséges hozzáférők körét a potenciális érdeklődőkre. Röviden: bemutatásra került, hogy a hallgatók, a fenntartó, illetve a könyvtár számára milyen előnyöket remélünk a bevezetéstől, amit leginkább úgy lehet összefoglalni, hogy erősödő személyes könyvtárosi támogatás megvalósítása, az automatizálhatóan is megválaszolható kérdések csökkentésével. A tervezés, beszerzés, bevezetés ugyanúgy erőforrás igényes feladat, mint a fenntartás. A chatbot fejlesztés célja tehát nem költségcsökkentés lesz, hanem a hallgatói sikeresség támogatása a diplomadolgozat-írás során. Az itt leírtak egy tervezett pilot projekt részei, amelyek talán megvalósíthatók lesznek a jövőben.

\section{Jegyzetek és irodalom}

1. FØLSTAD, Asbjørn, - BRANDTZÆG, Petter B.: Chatbots and the new world of HCI. = Interactions, Vol. 24. No. 4. 2017. 38-42. p. Forrás: http://doi.org/10.1145/3085558

2. FICHTER, Darlene - WISNIEWSKI, Jeff: Chatbots introduce conversational user interfaces. $=$ Online Searcher, Vol. 41. No. 1. 2017. 56-58. p.

3. WEIZENBAUM, Joseph: ELIZA - a computer program for the study of natural language communication between man and machine. = Communications of the ACM, Vol. 9. No. 1. 1966. 36-45. p. Forrás: https://doi.org/10.1145/365153.365168 [2020. április 28.]

4. SHAWAR, Bayan A. - ATWELL, Eric: Chatbots: are they really useful? = LDV Forum, Bd. 22. 1. 2007. 29-49. p. Forrás: https://jlcl.org/content/2-allissues/20-Heft1-2007/Bayan_ Abu-Shawar_and_Eric_Atwell.pdf [2020. április 29.]

5. The robots are coming? Libraries and artificial intelligence. Forrás: https://blogs.ifla.org/lpa/ 2018/07/24/the-robots-are-coming-libraries-and-artificial-intelligence [2019. október 15.]

6. What are the pros and cons of chatbots. APAC CIO outlook. 2019. augusztus 26. Forrás: https://www.apacciooutlook.com/news/what-are-the-pros-and-cons-of-chatbots-nwid5503.html [2019. október 27.]

7. CIECHANOWSKI, Leon [et al.]: In the shades of the uncanny valley: an experimental study of human-chatbot interaction. = Future Generation Computer Systems, Vol. 92. 2019. 539. p. Forrás: https://doi.org/10.1016/j.future.2018.01.055 [2019. október 15.]

8. GNEWUCH, Ulrich [et al.]: Faster is not always better: understanding the effect of dynamic response delays in human-chatbot interaction. $=$ ECIS 2018 Proceedings Collections Research Papers, 113. 2018. Forrás: https://aisel.aisnet.org/ecis2018_rp/113 [2019. október 29.] 


\section{WINKLER BEA}

9. BÁTFAI Norbert - BÁTFAI Mária Erika: Virtuális könyvtáros segítheti majd a kutatókat kézirataik beküldésében a Debreceni Egyetemen. = Tudományos és Műszaki Tájékoztatás, 58. évf. 1. sz. 2011. 10-14. p. Forrás: http://tmt.omikk.bme.hu/tmt/article/ view/791/10690 [2020. április 28.]

10. FICHTER, Darlene - WISNIEWSKI, Jeff: i. m. 56-58. p.

Winkler Bea - könyvtáros az Állatorvostudományi Egyetem Hutÿra Ferenc Könyvtár, Levéltár és Múzeum igazgatója. Az ELTE BTK Irodalomtudományi Doktori Iskola Könyvtártudományi Doktori Programjának doktorandusz hallgatója, kutatási témája a mesterséges intelligencia a könyvtárakban. ORCID: 0000-0001-9496-9549 